\title{
MERAWAT POTENSI SENI BUDAYA \\ MELALUI INOVASI SENI TRADISI \\ DESA PURBOSARI, KECAMATAN NGADIREJO \\ KABUPATEN TEMANGGUNG
}

\author{
Dwi Wahyudiarto \\ Jurusan Tari \\ Fakultas Seni Pertunjukan ISI Surakarta \\ Email: wahyudiarto@isi-ska.ac.id
}

\begin{abstract}
Abstrak
Merawat Potensi Seni Budaya Melalui Inovasi Seni Tradisi di Purbosari, Kec. Ngadirejo, Kab. Temanggung. merupakan program pemberdayaan masyarakat dalam menghidupkan seni tradisi. Laku kreatif dengan aktifitas budaya adalah satu cara dalam merawat agar tradisi tetap hadir, hidup dan menghidupi generasi jamannya. Program ini dilakukan dalam upaya mengingkatkan dan mengembangkan kualitas seni tradisi sebagai potensi budaya lokal. Sinergitas antara masyarakat sebagai pemilik budaya, dan akademisi sebagai penggerak dan pendorong kemajuan budaya, akan menghasilkan kemampuan kreatif bagi pelaku seni di Purbosari. Pemberdayakan masyarakat Purbosari dilakukan dengan menggunakan model Partisipatory Action Research (PAR), dalam model ini kegiatan diawali dengan penelitian, FGD berkait dengan seni tradisi, serta tindakan dalam memberikan inovasi terhadap seni tradisi di Purbosari. Program ini dilakukan melalui pelatihan, kolaborasi, dialog, maupun pentas bersama. Program yang dilakukan selama enam bulan ini merupakan langkah nyata dalam mendinamisasikan kehidupan seni budaya di masyarakat.
\end{abstract}

Kata kunci: Inovasi, Seni Tradisi, Pemberdayan Masyarakat.

\begin{abstract}
Caring for the potential of Art-Culture through traditional art innovation at Purbosari, Ngadirejo, Temanggung. is a community empowerment program in reviving traditional arts. Creative behavior with cultural activities is one way of caring for traditions to remain present, live and support the generation of their era. This program is carried out in an effort to improve and develop the quality of traditional arts as a potential of local culture. Synergy between the community as the owner of culture, and academics as the activator and driver of cultural progress, will produce creative abilities for the performers of art in Purbosari. Purbosari community empowerment is done by using the Participatory Action Research (PAR) model, in this model the activity begins with research, Focused Group Discussion is related to traditional arts, and actions in providing innovation to traditional arts in Purbosari. This program is carried out through training, collaboration, dialogue, and joint performances. The program, which has been carried out for six months, is a concrete step in moving dynamic the life of art and culture in society.
\end{abstract}

Keywords: innovation, traditional art, community empowerment. 


\section{Abdi Seni Jurnal Pengabdian Kepada Masyarakat}

\section{PENDAHULUAN}

\section{A. Latar Belakang}

Desa adalah kesatuan masyarakat hukum yang memiliki batas wilayah yang memiliki wenang untuk mengatur dan mengurus pemerintahan dan kepentingan masyarakat setempat berdasarkan prakarsa masyarakat desa hak asal usul, dan/atau hak tradisional yang diakui dan dihormati dalam sistem pemerintahan. Disamping itu, pemerintahan desa juga merupakan penyelenggaraan urusan pemerintahan demi kepentingan masyarakat setempat dalam sistem pemerintahan Negara Kesatuan Republik Indonesia.

Desa Purbosari Kecamatan Ngadirejo, Kabupaten Temangung, merupakan salah satu desa yang terletak sekitar dua puluh kilometer dari pusat kota Temanggung kearah barat laut. Pemerintahan Desa Purbosari membawahi lima dusun, yaitu dusun Liyangan, dusun Garon, dusun Karanganyar, dusun Bonganti, dan dusun Susukan. Mayoritas penduduknya memiliki Di desa Purbosari, tepatnya di dusun Liyangan, pada tahun 2008 ditemukan situs candi yang sampai sekarang masih terus digali. Penemuan pertama berupa talud, yoni, arca, dan batu-batu candi. Penemuan selanjutnya sebuah bangunan candi yang tinggal bagian kaki dan di atasnya terdapat sebuah yoni yang unik, tidak seperti umumnya, karena yoni ini memiliki tiga lubang. Penelitian dan penggalian lebih lanjut dilakukan Balai Arkeologi Yogyakarta pada th 2010 dan th 2011 menyimpulkan bahwa situs tersebut bukan merupakan candi besar, tetapi sebuah perdusunan yang diperkirakan peninggalan jaman Mataram Kuno. Penggalian situs candi Liyangan masih terus dilakukan sampai sekarang. Situs Liyangan merupakan situs dengan karakter kompleks; indikasi sebagai situs permukiman, situs ritual, sekaligus situs pertanian. Selaian situs candi, potensi budaya yang ada di Purbosari adalah kesenian Topeng Ireng, karawitan, santi swara, drundband, angklung, paduan suara, kerajinan, serta tempat rekreasi berupa kolam renang.Selain seni pertunjukan juga terdapat ritual upacara sadranan bersih desa yang dilaksanakan satu tahun sekali.

Dari potensi seni budaya seperti disebut diatas, pemerintah Kabupaten Temanggung, dan Kepala Desa Purbosari berharap wilayah desa Purbosari bisa menjadi desa wisata. Akan tetapi hal ini belum bisa terwujud, mengingat bahwa masyarakat desa Purbosari adalah petani tradisi yang secara turun-temurun mengelola lahan untuk menanam tembakau. Dalamkondisi seperti tersebut, secara substansi cukup susah untuk mengubah meansead warga masyarakat Purbasari yang masih sangat kuat dengan pola petani tembakau, menjadi masyarakat yang bisa menjual aset desa melalui wisata. Masyarakat belum menyadari sepenuhnya, bahwa pola kehidupan mereka sehari-hari dalam bertani tembakau mulai dari tanam sampai pada pengemasan tembakau bisa digunakan sebagai obyek wisata, sepanjang ditangani dan di kemas secara baik. Ditambah lagi ragam potensi seni pertunjukan dan kerajinan yang ada di Purbosari, sangat memungkinkan dikemas sebagai atraksi budaya untuk kebutuhan wisata. Untuk mempersiapkan Purbosarimeningkatkan kualitas dan sumber daya manusia dalam olah budaya, diperlukan kesiapan terutama kemasan seni pertunjukan, agar lebih menarik dan atraktif. Hal ini bisa dilakukan dengan memberdayakan masyarakat untuk terus merawat semua potensi seni, serta memberikan inovasi kreatifberbasis kekuatan tradisi lokal.

\section{B. Tujuan dan Manfaat}

Pengabdian Pada Masyarakat Tematik dengan tema "Merawat Potensi Seni Budaya Melalui Inovasi Seni Tradisi di Desa Purbasari”, adalah program memberdayakan masyarakat untuk terus merawat, melestarikan, mengembangkan dan menggali semua potensi budaya, yang akhirnya berdampak pada kebutuhan wisata. Hal ini sangat penting kaitannya dengan mengkemas senibudaya, menguatkan identitas, dan promosi desa Porbasari sebagai rintisan desa wisata. Dengan kegiatan pengabdian pada masyarakat ini, diharapkan dapat 
memenuhi keinginan masyarakat dalam upaya meningkatkan apresiasi masyarakat dan seniman agar berjiwa inovatif, kreatif serta dinamis untuk terus menjaga seni budaya berbasis budaya lokal.

\section{TINJAUAN PUSTAKA}

Buku Seni Pertunjukan Indonesia \& Pariwisata oleh Soedarsono, Pariwisata dan dampaknya terhadap seni pertunjukan secara rinci dipaparkan dalam buku ini. Industri pariwisata yang ada di Indonesia saat ini memberi peluang terhadap pendapatan seniman, di samping membawa dampak terhadap perubahan seni pertunjukannya karena kehadiran seni pertunjukan di sini untuk memenuhi pasar pariwisata, maka akan terjadi suatu kemasan.

Buku Metodologi Kajian Tradisi Lisan, oleh Prudentia, buku ini membahas kajian pertunjukan, pendekatan folklor dalam penelitian bahan-bahan tradisi lisan, merekam pertunjukan tradisional, tantangan penggandaan lisan dan komunikasi lisan sebagai tradisi lisan. Pada dasarnya kajian buku ini lebih terfokus pada kajian sastra dalam kata, suara, gerak, dan rupa.

S.C. Utami Munandar dalam Kreatifitas dan Keberbakatan, Strategi Mewujudkan Potensi Kreatif dan Bakat, buku ini memberi masukan pengusul bagaimana memberikan pengkayaan dan percapatan, model pembelajaran, serta tehnik kreatif dan pemecahan masalah, termasuk tehnik futuristik yang menyiapkan seseorang untuk kompeten menghadapi masa depan yang penuh tantangan.

Dwi Wahyudiarto, Sri Rochana W, Pengantar Koreografi, Dari tulisan ini, dapat dipetik pemahaman proses koreografi serta penggarapan unsur gerak (tompo, dinamik dan ruang) dalam garapan tari. Penggarapan dimaksud termasuk pula desain lantai, level, skenario serta bgaimana membuat alur garapan dalam koreografi tari.

Aspek-aspek Koreografi Kelompok oleh Sumandiyo Hadi. Daribuku ini didapat pemahaman bagaimana menyusun koreografi kelompoh untuk sebuah pergelaran tari. Bagaimana hubungan antar penari, dalam garapan tari, bagaimana ekplorasi, improvisasi, dan pembentukan skrip atau skenario tari.

Pertunjukan dari Perspektif Politik, Sosial dan Ekonomi, oleh Soedarsono. Buku ini sebuah paparan yang sangat komplek tentang prespektif politik, sosial dan ekonomi dalam konteks seni pertunjukan, Sebuah kajian menarik mengenai berbagai jenis seni pertunjukan dari sudut pandang politik, sosial, dan ekonomi. Pembahasan tidak hanya terbatas pada keberadaan seni pertunjukan yang ada di Indonesia saja, namun juga di luar negeri.

\section{METODE}

Seni tradisi yang ada di pedesaan merupakan perwujudan nyata dari ekspresi yang jujur dari masyarakatnya. Bagi masyarakat desa, seni adalah bagian penting untuk menyampaikan kemerdekaan berekspresi, dan berbagai macam peluang untuk mengekspresikan diri dan kelompoknya. Seni tradisi di desa akan mati kalau didoktriner, tidak diberi peluang kebebasan bagi pribadi pemiliknya. Pemahaman tradisi itu sebenarnya adalah tradisi kreatif, kreatifitas yang mentradisi bagi pemiliknya. Seni tradisi diharapkan dan harus tetap eksis di masa mendatang, untuk itu dibutahkan berbagai cara, gagasan, serta langkahlangkah sebagai upaya agar seni tradisi tetap eksis dijamannya.

Masyarakat desa Purbosari berada dalam kehidupan tradisi petani yang ayem tentrem, mapan dan damai, hal ini membuat kurang dinamisnya seni budaya yang ada. Oleh karenanya perlu tindakan nyata, agar seni budaya tradisi tetap hidup, ini bisa dilakukan dengan merawat dengan baik. Merawat dalam pengertian melestarikan, mengembangkan bahkan memberikan inovasi baru, agar keberadaan seni tetap hidup. Untuk merealisasikan tujuan dalam PPM Tematik di desa Purbasari, diperlukan metode dan langkah nyata.

Program Pengabdian Pada Masyarakat Tematik yang dilakukan di Purbosari, lebih 


\section{Abdi Seni Jurnal Pengabdian Kepada Masyarakat}

mengadopsi metode Participatipatory Action Research (PAR). PAR merupakan aktifitas yang melibatkan secara aktif semua pihak-pihak yang relevan (stakeholders), dalam rangka melakukan perubahan dan perbaikan ke arah yang lebih baik. Dalam metode ini, terdapat tiga hal yang penting yaitu, keterlibatan langsung dari warga, tindakan nyata, serta ada penelitian atau research.

Program PPM Tematik ini lebih difokuskan pada kegiatan seni budaya, akan tetapi untuk mengaplikasikan metode ini harus memahami konteks masyarakat secara umum. Untuk itu harus melakukan refleksi kritis terhadap konteks tradisi budaya, ekonomi, geografis, dan konteks lain-lain yang terkait. Hasil diskusi awal yang dilakukan secara partisipatifkemudian diimplementasikan ke dalam aksi. Aksi yang didasarkan pada riset partisipatif yang benar akan menjadi tepat sasaran. Sebaliknya, aksi yang tidak memiliki dasar permasalahan dan kondisi subyek penelitian yang sebenarnya akan menjadi kontraproduktif

Metode PAR, merupakan pendekatan untuk mempelajari kondisi dan kehidupan pedesaan. Dengan kata lain dapat disebut sebagai metode pendekatan yang memungkinkan masyarakat desa untuk saling berbagi, meningkatkan, dan menganalisis pengetahuan mereka tentang kondisi dan kehidupan desa, termasuk seni tradisi, kemudian membuat rencana dan bertindak. Secara garis besar ada tiga kegiatan yang dilakukan dalam aplikasi metode PAR untuk kegiatan pemberdayaan masyarakat dalam merawat potensi seni budaya, melalui inovasi seni tradisi. Pertama adalah melihat kembali tradisi yang ada di Purbasari, kedua mempertanyakan tradisi dan yang ketiga adalah mereinterpretasi seni tradisi.

Melihat tradisi dalam konteks pelaksanaan PPM Tematik ini adalah mencoba untuk memahami budaya tradisi yang ada di Purbosari. Dalam pemahaman ini tentu saja tidak sebatas pada keseniannya saja, akan tetapi juga budaya tradisi di Purbosari secara menyeluruh. Budaya tradisi Purbosari yang akan dipahami antara lain; kondisi geografis, sumber daya manusia, aktifitas masyarakat, seni budaya, yang kesemuanya akan sebagai pijakan dalam melakukan inovasi terhadap seni tradisi yang ada di Purbosari, sebagai upaya untuk merawat keberlangsungan potensi seni tradisi.

Mempertanyakan, mengkritisi, serta manganalisa seni tradisi yang ada di masyarakat Purbosari, merupakan langkah kongkrit yang harus dilakukan dalam kegiatan ini. Mempertanyakan tradisi, dilakukan melalui penelitian terbatas terhadap keberadaan seni tradisi di Purbasari. Setelah mendapatkan data dari penelitian awal, melalui wawancara, diskusi dengan warga dilanjutkan dengan banyak membincangkan perihal tradisi yang ada di Purbosari, khususnya seni tradisi. Perbincangan dilakukan secara mendetail berkait dengan seni tradisi yang ada di Purbosari; misalnya tentang bentuk sajian, peserta atau regenerasi, konsep-konsep seni pertunjukan, sistem pelatihan, serta kegiatan lain yang menunjang keaberadaan seni tradisi. Dengan tindakan ini maka kita mengetahui celah-celah yang bisa dikembangkan, sehingga inovasi dan kreasi yang dilakukan tetap berbasis pada kekuatan busala lokal.

Tindakan untuk mereinterpretasi, mengaktualkan, membangkitkan kembali seni tradisi, melalui pelatihan, workshop, kolaborasi, sarasehan, serta pergelaran bersama, dalam kontek merawat, melestarikan seni tradisi di Purbasari bisa diwujudkan. Dengan tiga langkah tersebut diatas, secara konsep dan aplikatif kegiatan PPM Tematik ini bisa dilakukan dengan baik.

\section{PEMBAHASAN}

Pelaksanaan keseluruhan kegiatan dilakukan selama enam bulan, yang dimulai dari persiapan awal, koordinasi, pelatihan, workshop, sarasehan dan pertunjukan akhir program. Langkah awal program ini adalah melakukan persiapan awal dengan membuat rancangan kegiatan secara mendetail dalam bentuk proposal. Selanjutnya propoal digunakan untuk melakukan koordinasi dengan masyarakat sebagai obyek kegiatan. Tahap selanjutnya adalah survey secara terbatas dengan 
bertemu pejabat pamong desa, tokoh masyarakat dan karangtaruna. Dari survey awal didapatkan informasi tentang potensi seni budaya serta kebutuhan masyarakat dan yang sesuai dengan program PPM Tematik ISI Surakarta. Dengan demikian, terlaksanannya program ini akan bermanfaat bagikedua belah pihak.

Langkah selanjutnya adalah koordinasi, koordinasi dilakukan dengan memberikan pemahaman rencana kegiatan PKM kepada masyarakat Purbosari, mulai dari tingkat kabupaten (Bapeda, Kecamatan, Kalurahan, kepada dusun, serta tokoh masyarakat, hal ini perlu dilakukan agar pelaksanaan program bisa berjalan dengan baik. Dalam koordinasi tim PPM Tematik memberikan sejelasnya terkait dengan rencana kegiatan dan tujuan yang diatur dalam jadwal kegiatan secara utuh,

Setelah koordinasi dilakukan, dilanjutkan dengan mulai menyusun rencana kegiatan dalam bentuk jadwal kegiatan, yang dilakukan oleh tim pelaksana program bersama dengan masyarakat. Pelaksanaan kegiatan pelatihan dilakukan di desa Purbosari, Ngadirejo, Temanggung. Materi yang diberikan difokuskan pelatihan seni, peningkatan apresiasi dalam bentuk dialog atau sarasehan, serta menyusun bentuk senikolaborasi dengan masyarakat Purbosati. Jadwal pelatihan akan diatur bersama masyarakat untuk mencari waktu yang tepat, mengingat kegiatan mayarakat banyak dilakukan pada waktu pagi hari, oleh karenanya kemungkinan latihan dilakukan pada waktu siang dan sore hari. Adapun kegiatan yang dilakukan diantaranya adalah;

\section{Sarasehan Budaya}

Sarasehan budaya dilakukan dengan mengundang dua orang narasumber; satu orang bapak Doto Yogantoro, dari Yogyakarta seorang pakar dan pengelola desa wisata, dengan materi pembahasan "Membangun Desa Wisata Berbasis Budaya Kreativitas". Narasumber kedua adalah Dwi Wahyudiarto, S.Kar., M.Hum seorang akademisi, dengan materi pembahasan "Kekuatan Tradisi Kita". Acara sarasehan dilaksanakan tanggal 10 Agustus 2018, bertempat di aula desa Purbasari,
Ngadirejo, Temangung. Dalam sarasehan dilibatkan semua perangkat desa Purbasari, tokoh masyarakat, Kelompok Sadar Wisata (Pokdarwis), pelaku seni, karang taruna dan ibu-ibu PKK.

Sarasehan dilakukan untuk memenuhi permintaan masyarakat, yang berharap dengan potensi budaya lokal bisa mengangkat desa Purbasari menjadi desa Wisata.

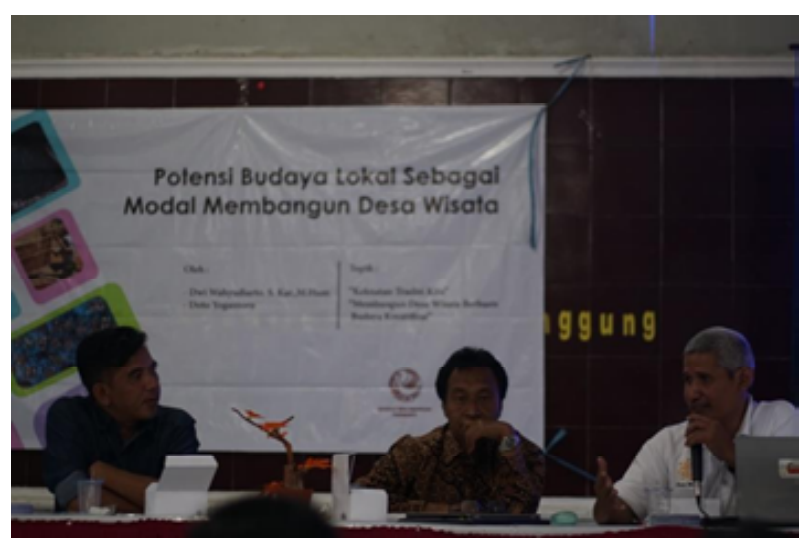

Gbr. 1. Sarasehan budaya dengan tema Potensi Budaya Lokal Sebagai Modal membangun Desa

Wisata, dilakukan untuk memberikan apresiasi masyarakat, bagaimana membangun budaya lokal sebagai aset daerah.

\section{Pelatihan Seni Karawitan, Angklungdan Rontek.}

Pelatihan karawitan kepada remaja desa Liangan bertujuan untuk mengenalkan gending atau lagu dalam karawitan dan cara memainkannya melalui gamelan jawa. Selain itu juga untuk dipentaskan dalam acara akhir kegiatan. Kegiatan ini dilakukan hampir setiap hari di balai desa Purbosari pada sore hari dan malam hari. Dengan demikian remaja Liyangan dapat lebih memahami dan mencintai budaya bangsa lewat karawitan tersebut, dan nantinya juga dapat diajarkan ulang kepada adik-adiknya yang masih kecil.

Kegiatan pelatihan Karawitan dan Angklung juga diberikan untuk anak-anak sekolah, dan pelaku seni serta karang taruna. Untuk anak-anak seusia SD, dilakukan di SDN Purbosari 1, dan anak-anak warga desa Liyangan. Program pelatihan dengan 
memberikan materi kepada anak-anak seusia kelas 4,5,6. Materi lagu yang diberikan masih bersifat dasar, hal ini sebagai apresiasi dan menarik anak-anak usia diniuntuk mencintai kembali bermain karawitan. Hasil dari program kerja ini digunakan untuk acara karnava HUT RI pada 18 Agustus 2018, dan dipentaskan pada akhir kegiatan pelatihan. Sedangkan untuk karang taruna dan remaja, diberikan materi garap iringan tari. Dengan harapan bisa menambah pengetahuan, pengalaman, dan melatih mental.

Selain pelatihan Karawitan dan Angklung, tim juga memberikan pelatihan seni musik Rontek, kepada remaja Liyangan sebagai edukasi dan membuka wawasan tentang keberagaman musik di Nusantara. Dalam kegiatan ini dijelaskan apa itu musik Rontek, bagaimana cara membuat dan cara memainkannya. Selain itu remaja dapat membuat music kreasi baru dari kasus musik Rontek. Kegiatan ini dilakukan pada sela-sela latihan karawitan berlangsung, yaitu pada sore hari dan malam hari. Latihan tersebut bertujuan untuk melatih kreatifitas remaja Liyangandalam mengolah sumber daya alam di sekitar seperti bambo. Selain untuk pembelajaran, latihan musik Rontek, juga sebagai materi pentas dalam acara akhir program, dan juga untuk acara-acara lainnya di desa Purbasari.

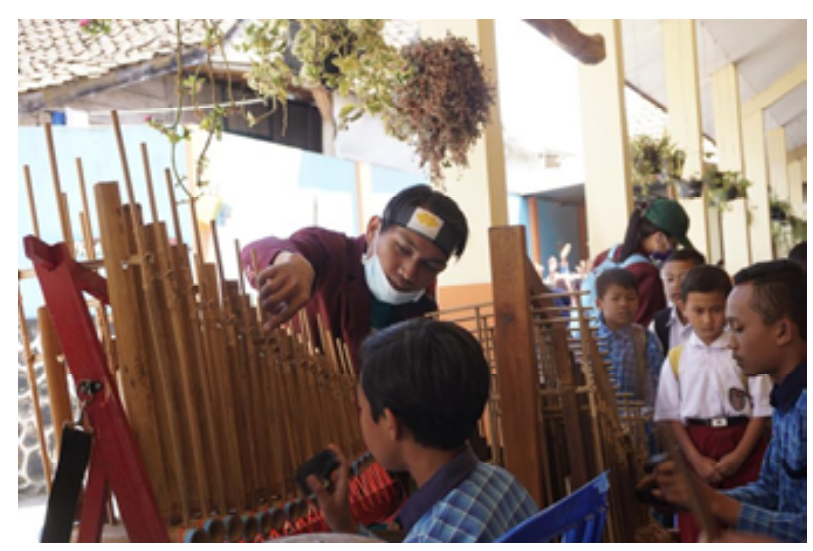

Gbr. 2. Pelatihan musik Angklung bagi anak-anak sekolah dasar..

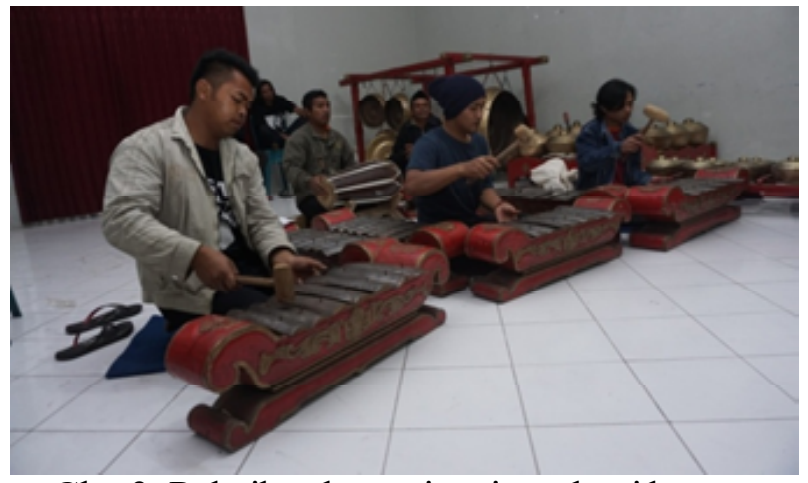

Gbr. 3. Pelatihan karawitan jawa bagi karang taruna desa Purbasari

\section{Pelatihan Tari}

Pelatihan Tari lebih difokuskan pada anakanak dan remaja, dengan harapan ditangan merekalah tonggak estafet seni budaya akan dilanjutkan. Pelatihan dipusatkan di dusun Liyangan, untuk materi tari anak-anak, dipilihkan materi yang segar dan meriah yaitu tari Gugur Gunung, dan tari Bunga. Tari Gugur gunung merupakan kreasi tim pelaksana, yang mencoba manyatukan ragam gerak dari tari tradisi yang ada di Liyangan.

Untuk kelompok remaja dan karang taruna, dipilihkan materi baru, yaitu garapan tari yang mengambil ide cerita dan spririt dari masyarakat Purbosari. Garapan tari yang dilatihkan adalah sendratari dengan judul "Babad Liyangan". Sendratari Babad Liyangan menceritakan tentang kehidupan sehari-hari warga Dusun Liyangan. Selain garapan tari Babad Liyangan, juga diajarkan tari Guyub. Tari ini terinspirasi dari kegiatan petani yang akan berangkat ke lading tembakau. Garapan tari lebih memilih gerakan kaki dan permainan peroperti caping dikarenakan desa Purbosari terletak di lereng gunung Sindoro dan dipilih properticaping lebih identik dengan petani. Dalampertunjukannya, tari ini dikalaborasikan dengan musik tradisional jawa yaitu musik Karawitan.

Pelatihan tari juga dilakukan di Sekolah Dasar Negeri Purbosari I, diharapkan materi yang diberikan bisa digunakan untuk kegiatan pentas seni bagi sekolah. Tari yang diajarkan adalah tari kreasi dengan tema tari Bendera. Tari ini disiapkan untuk 
keperluan karnaval di Purbosari. Materi dipilih karena sederhana, mudah dipahami dengan cepat oleh anak- anak seusia sekolah dasar. Tari ini memadukan ragam tari dan bentuk ragam bentuk karnival, seperti gerak tangan ke kiri, ke kanan, kaki jinjit dan tehnik memegang bendera dengan benar. Proses pelatihan anak- anak SD N 1 Purbasari berjalan selama sebulan dengan selang waktu 3 kali seminggu. Proses latihan dilakukan secara bertahap mulai dari dasar, sampai pada kesiapan peserta untuk ikut pentas. Pada pertemuan pertama diajarkan tehnik memegang bendera dengan benar agar bendera tidak jatuh pada saat digerakkan. Pertemuan selanjutnya masih diajari tehnik-tehnik dasar seperti baris berbaris dengan rapi dan benar, begitu pula dengan pertemuan selanjutnya dengan lebih memantapkan gerakan yang sudah di berikan dan pada pertemuan sebelumnya. Pada latihan minggu terakhir mereka sudah bisa menguasai tehnik-tehnik yang diajarkan dan sesuai dengan harapan hasilnyapun sangat memuaskan dan dapat memeriahkan dan berpatisipasi hari kemerdekaan Indonesia pada tanggal 17 Agustus2018.

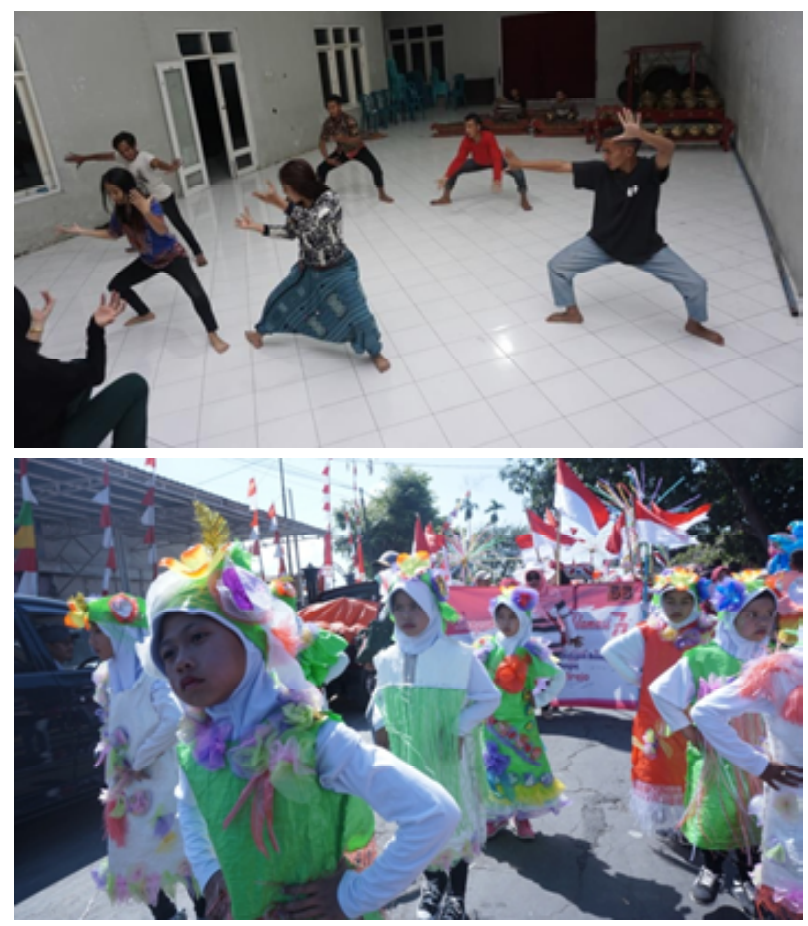

Gbr. 4. Pelatihan tari bagi karang taruna desa Purbasari

\section{Pelatihan Pranatacara}

Pelatihan Prana tacara, dilaksanakan di dusun Liyangan bertujuan untuk memperkenalkan dan menambah pengetahuan tentang teks bahasa jawa kepada pemuda, dan diharapkan menjadi generasi penerus dalang manten didusun Liyangan.

\section{Pelatihan Kristik, Sungging dan Ornamen.}

Workshop kerajinan kristik dilaksanakan di aula Balai Desa Purbosari. Workshop diikuti oleh Ibu-Ibu PKK desa Purbosari yang berjumlah sekitar 22 orang. Kegiatan ini diberikan pada ibuibu PKK untuk menambah wawasan mereka tentang kerajinan kristik, diharapkan kegiatan ini dapat dijadikan sebagai peluang usaha dibidang kesenian selain menjadi petani tembakau, agar dapat menambah nilai ekonomis warga setempat. Kegiatan workshop berjalan dengan lancar dan materi tersampaikan dengan baik. Hal ini terbukti dengan antusias dari ibu-ibu yang semangat untuk melanjutkan dan meminta untuk diadakannya pelatihan lagi.

Selain Kristik, juga dilakukan pelatihan sungging yang diikuti oleh muda mudi dusun Liangan. Menyungging merupakan hal baru bagi mereka, sehingga dalam pemberian materi dilakukan dengan bahasa yang sederhana agar dapat dipahami. Hasil pelatihan, semua karya yang mereka buat akan dipamerkan pada saat acara akhir program. Hal ini membuat mereka semangat untuk menyelesaikan karyanya semaksimal mungkin.

Pelatihan menggambar ornament diberikan pada siswa / kelas 3 SD PurbasariI. Dalam pelatihan ini diberikan materi dengan bahasa yang sesederhana mungkin agar dapat dipahami. Dalam kegiatan mengajar ini tidak hanya memberikan materi dan contoh didepan saja tetapi juga langsung memberikan contoh dan menghampiri pada setiap siswa yang bertanya. Setelah kegiatan ini diharapkan etiap siswa dapat mengembangkan dan berkreasi dengan menggambar ornamen untuk menambah wawasan mereka bidang kesenian. Darihasil kegiatan gambar adik-adik akan 


\section{Abdi Seni Jurnal Pengabdian Kepada Masyarakat}

dipamerkan pada saat acara akhir program sehingga dapat menambah semangat mereka untuk terus berkarya.

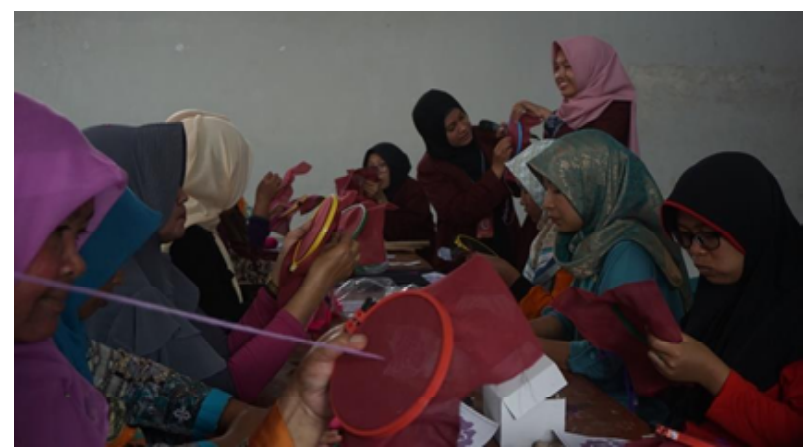

Gbr. 4. Pelatihan kristik bagi ibu-ibu PKK desa Purbasari

\section{Pelatihan Membuat Kostum Karnaval, dan Batik Jumputan}

Pelatihan membuat kostum karnaval, diberikan kepada para siswa dan guru sekolah dasar. Dalam pelatihan langsung diaplikasikan bagaimana membuat kostum karnival dari bahan dasar yang ada di Purbasari. Dalam membuat kostum ini diperlukan kretifitas dikarenakan adanya alat dan bahan yang terbatas. Kostum dibuat dari bahan bekas yang sudah tidak digunakan lagi. Bahan-bahan tersebut seperti; karung beras, plastik, dan juga raffia. Barang bekas dipilih karena sebagai bentuk cinta lingkungan yaitu memanfaatkan barang yang sudah tidak terpakai lagi. Hasil pembuatan kostum ini dipakai saat karnaval memperingati hari Kemerdekaan di Kecamatan Ngadirejo.

Materi pelatihan batik Jumputan yang diberikan kepada siswa kelas 4, 5 dan 6 SD N 1 Purbosari. Pelatihan dengan mengajar ananak-anak membuat motif batik dengan cara mengikat kencang beberapa bagian kain yang kemudian dicelupkan kedalam pewarna. Hasil yang dicapai adalah anakanak dapat mengerti dan berlajar tentang batik jumputan. Selain batik Jumputan, muda-mudi karang taruna Dusun Liyangan juga diajari tekhnik pembuatan batik tulis dari proses penciptaan motif, mencanting, pewarnaan, pelorodan hingga menjadi kain batik. Hasil yang dicapain adalah muda-mudi karang taruna dapat mengerti dan belajar tentang pembuatan batik tulis.

Untuk melihat hasil capaian kegiatan, maka diakhir kegiatan dilaksanakan pergelaran, berupapentas secara bersama.Hal ini merupakan bagian yang cukup penting, karena sebagai salah satu pendorong bagi masyarakat yang telah mengadakan latihan. Pentas akan dilakukan apabila kesiapan semuanya sudah memenuhi kualitas garapan yang ditentukan. Tempat pentas diarea Parkir taman candi Liyangan, dusun Liyangak, Desa Purbosari

\section{KESIMPULAN}

Merawat potensi seni budaya, melalui inovasi seni tradisi di desa Purbosari adalah bentuk pemberdayaan masyarakat yang merupakan bagian dari kerjasama antara Institut Seni Indonesia Surakarta, dengan Pemerintah Kabupaten Temangung, serta seluruh masyarakatnya. Kerjasama ini sangat bermanfaat bagi kedua belah pihak. Bagi Institut Seni Indonesia Surakarta kerjasama ini merupakan tugas utama dalam mengaplikasikan tridarma perguruan tinggi yaitu pendidikan, penelitian dan pengabdian pada masyarakat. Bagi pemerintah Kabupaten Temanggung beserta seluruh masyarakatnya, kerjasama ini akan dapat meningkatkan kualitas potensi seni budaya.

Dalam kerjasama dimaksud, Pemerintah Kabupaten Temanggung, pemerintah Kecamatan Ngadirejo, dan khususnya Pemerintah Desa Purbosari, telah memfasilitasi semua sarana, prasarana, regulasi perencanaan seluruh kegiatan. Hal ini merupakan wujud nyata keseriusan pemerintah daerah dalam usaha memajukan dan mengembangkan bidang seni budaya. Sedangkan Institut Seni Indonesia Surakarta, sebagai akademisi, akan bertanggungjawab terbadap arah dan kualitas program kegiatan.

Program yang berupa; pelatihan, workshop, sarasehan, kolaborasi, serta pergelaran yang dilakukan adalah bagian dari upaya merawat, dan 
melestarikan seni tradisi dimPurbosari. Hal ini sangat penting dilakukan untuk mengaktualisasikan kekuatan budaya lokal lebih mengkini. Selain itu juga mampu memberikan nilai tawar baru, sehingga membuat seni tradisi terus hadir di masyarakat. Adapun beberapa ragam seni tradisi yang di garap dalam program PPM Tematik ini diantaranya adalah; seni tari, musik, karawitan, angklung, kristik, musik bambu, serta seni lainnya yang ada di Purbosari. Dalam arus informasi yang global seperti sekarang, sangat penting menancapkan dan mengangkat seni tradisi sebagai fondasi dan arah pengembangan kedepan.

Pelatihan yang dilakukan dalam program PPM Tematik ini melibatkan siswa SD, Paud, Karang Taruna, remaja, seniman, guru, ibu-ibu PKK, kelompok Pokdarwis, di seluruh desa Purbosari. Dengan kebersamaan dan semangat yang begitu tinggi dari masyarakat Purbosari, rasanya di lereng gunung Dieng, dan di daerah hamparan tembakau tersebut kedepan optimis tetap memiliki kekayaan budaya tradisi yang menjadi pesona daerah. Proses kerja PPM Tematik juga merupakan tranfer kwonlade lintas generasi pemangku seni tradisi.

Desa Purbosari yang sangat indah dengan hamparan tembakau yang subur, seketika menjadi hidup dengan aktifitas pelatihan seni tradisi. Program pelatihan ini diharap terus terjaga, agar letupan energi spirit seni tradisi terus memancar menggema, diantara hiruk pikuk era global. Hal ini juga sangat tergantung dari masyarakat Purbosari dalam terus menjaga dan mengembangkan kekuatan seni tradisi mereka. Apabila seni tradisi terus dirawat dan dilestarikan, maka akan semakin memantapkan kekuatan budaya Purbosari menjadi bagian hidup dan kehidupan masyarakat, serta merambah sebagai aset wisata yang berdampak pada nilai ekonomi bagi masyarakat.

\section{DAFTAR PUSTAKA}

Afandi, Agus,dkk.,Modul Participatory Action
Research
Pengorganisasian Masyarakat (Community Organizing), Surabaya: LPPMUIN Sunan Ampel, 2015

Alwasilah, A. Chaedar,. Pokoknya Kualitatif : Dasar-dasar Merancang dan

Melakukan Penelitian Kualitatif. Bandung: PT Dunia Pustaka Jaya dan Pusat StudiSunda. Th 2002

Awang, San Afri, 1995. "Pemberdayaan Masyarakat dan Kelembagaan Lokal dalamProgram IDT: Studi Kasus Tipologi Desa Hutan di Kabupaten Madiun”. DalamMubyarto (ed.), Program IDT dan Pemberdayaan Masyarakat. Jakarta: Aditya Media.

Saputro,. Thomas. 2014. Metode Pemberdayaan Masyarakat (PRA Dan RRA).

Sal Murgiyanto,Tradisi dan Inovasi: Beberapa Masalah Tari di Indonesia, Jakarta: Wedatama Widya Sastra, 2004.

Soedarsono, Pertunjukan dari Perspektif Politik, Sosial dan Ekonomi

Yogyakarta : Gadjah Mada University Press, 2003. Soedarsono. Seni Pertunjukan Indonesia \& Pariwisata.

Bandung, Masyarakat Seni Pertunjukan Indonesia (MSPI), 1999

Sumandiyo Hadi, Aspek-aspek Koreografi Kelompok, Yogyakarta, ISI Press.

Sri Rochana W, Dwi Wahyudiarto,, Pengantar

Koreografi, Surakarta, STSI Press. 2007

\section{Narasumber}

1. Arso, 35 tahun, Petugas Situs Liyangan

2. Soifudin Anshori, 47, Kepala Desa Purbasari

3. Istiawan, 40, Ketua Kelompom Sadar Wisata, Purbosari

4. Eko, 35 Pengelola Wisata Mandiri

5. Sudarsono, 50, Tohoh Masyarakat Purbosari

6. Abdi, 25 Kepala Dusun Liyangan 